\title{
Références
}

\section{Remarques :}

- Toutes les publications de l'AAPM, de l'ASN, de l'EFOMP, de l'ESTRO, de l'IAEA, de l'IOMP, de la SFPM sont librement téléchargeables (cf. liens utiles p. 212).

- Pour faciliter la navigation, les liens pointant sur certaines publications ont néanmoins été conservés dans cette liste de référence.

- Certaines des publications importantes des organismes institutionnels (ASN, IRSN, MEAH) sont référencées directement dans le guide sous forme de notes de bas de page.

- Tous les liens hypertexte du document sont réputés valables à la date du 30 juin 2012.

AAPM 1993, "Medical accelerator safety considerations: report of the AAPM Radiation Therapy Committee Task Group n 35", Med Phys 20(4), 1261-1275.

AAPM 1997, "Code of practice for brachytherapy physics: report of the AAPM Radiation Therapy Committee Task Group n56", Med Phys 24(10), 1557-1598.

AAPM 2003, "The solo practice of medical physics in radiation oncology : report of Task Group 11" The American Association of Physicists in Medicine,

http://aapm.org/pubs/reports/ 
AAPM 2009, "Code of Ethics for the American Association of Physicists in Medicine: report of Task Group n¹09", Med Phys 36(1), 213-223.

AAPM 2010, "Recommended ethics curriculum for medical physics graduate and residency programs: report of Task Group n¹59", Med Phys 37(8), 4495-4500.

AAPM 2011, "A dosimetric uncertainty analysis for photon-emitting brachytherapy sources: report of AAPM Task Group n 138 and GEC-ESTRO", Med Phys 38(2), 782801.

Alfonso R, Andreo P, Capote R, Huq M, Kilby W, Kjäll P, Mackie TR, Palmans H, Rosser K, Seuntjens J, Ullrich W \& Vatnitsky S 2008, "A new formalism for reference dosimetry of small and nonstandard fields [letter.]", Med Phys 35(11), 5179-5186.

ASN 2006, Revue contrôle n 168, « Le risque ».

ASN 2009, Revue contrôle $n^{\circ}$ 185, "La sécurité des traitements en radiothérapie externe : le point de vue des acteurs français ».

ASN 2011, Revue contrôle n 192, «Imagerie médicale. Maîtriser les expositions aux rayonnements ionisants ».

Breen SL \& Gérard K 2010, "Process Control and Quality Improvement", in "Quality and Safety in Radiotherapy", Pawlicki T, Dunscombe PB, Mundt AJ and Scalliet P editors, Taylor \& Francis, p. 37-42.

Bushberg JT, Seibert JA, Leidholt EM \& Boone JM 2011, Essential Physics of Medical Imaging, Lippincott Williams \& Wilkins (third edition).

Christofides S 2009 "The European federation of organisations for medical physics policy statement No. 13 : Recommended guidelines on the development of safety and quality management systems for medical physics departments ", Physica Medica 25(4), 161-165.

CIPR 2003, " Prévention des expositions accidentelles chez les patients recevant une radiothérapie ", Publication 86 de la Commission Internationale de Protection contre les Rayonnements lonisants, IRSN éd., EDP Sciences - traduction de la publication ICRP 2000.

CIPR 2007, Publication 103 : «Recommandations 2007 de la Commission Internationale de Protection Radiologique », édition en langue française TEC\&DOC Paris, IRSN 2009. http://www.icrp.org/docs/P103_French.pdf

Daniellou F, Simard M \& Boissières | 2010, « Facteurs humains et organisationnels de la sécurité industrielle : Un état de l'art », Les cahiers de la sécurité industrielle, Fondation pour une Culture de Sécurité Industrielle http://www.icsi-eu.org/francais/dev_cs/ cahiers/CSI-FHOS-Etat-de-l-art.pdf

Derreumaux S, Etard C, Huet C, Trompier F, Clairand I, Bottollier-Depois JF, Aubert B \& Gourmelon P 2008, "Lessons from recent accidents in radiation therapy in France", Radiat Prot Dosimetry 131(1), 130-135.

Desroches A, Leroy A, Quaranta JF \& Vallee F 2006, Dictionnaire d'analyse et de gestion des risques, Paris : Hermes Science, Lavoisier.

Desroches A, Leroy A \& Vallee F 2007, La gestion des risques : principes et pratiques, $2^{\mathrm{e}}$ édition revue et augmentée. Paris : Hermes Science, Lavoisier.

EFOMP 1984 - policy statement $n^{\circ} 2$, "The Roles, Responsibilities and Status of the Clinical Medical Physicist".

EFOMP 1993 - policy statement n5, "Departments of Medical Physics - Advantages, Organisation and Management". 
EFOMP 1994 - policy statement $n^{\circ}$ 6, "Recommended guidelines of National Registration Schemes for Medical Physicists".

EFOMP 2003 - policy statement n¹1, "Guidelines on professional conduct and procedures to be implemented in the event of alleged misconduct".

EFOMP 2006 - Malaga declaration : EFOMP's position on medical physics in Europe.

EFOMP 2009 - Policy statement n¹3 : voir Christofides.

EFOMP 2010 - Policy statement $n^{\circ} 12$ : voir Eudaldo \& Olsen.

ESTRO 2004 - Booklet n7, "Quality Assurance of Treatment Planning Systems. Practical examples for non-IMRT photon beams".

ESTRO 2004 - Booklet $n^{\circ} 8$, "A practical guide to quality control of brachytherapy equipment", Venselaar and Perez-Calatayud ed., European Guidelines for Quality Assurance in Radiotherapy series".

Eudaldo T \& Olsen K 2010, "The European Federation of Organisations for Medical Physics. Policy Statement $n^{\circ} 12$ : The present status of Medical Physics Education and Training in Europe. New perspectives and EFOMP recommendations", Physica Medica 26(1), 1-5.

Faulkner K, Schultz F \& Zoetelief H 2008, "Safety and efficacy for new techniques and imaging using new equipement to support European legislation, EC SENTINEL Project Workshop Proceedings", Radiation Protection Dosimetry, special issue, 129, n¹-3.

Fessler JM 2009, Cindyniques et santé : Contribution des sciences du danger à la santé, Economica éditeur.

Hendee WR 2011, "Patient safety and the Medical Physicist", Med Phys 38(6), [i-ii].

Hendee WR \& Herman MG 2011, "Improving patient safety in radiation oncology", Med Phys 38(1), 78-82.

Horton 2005, "Acceptance tests and commissioning measurements", in Radiation Oncology Physics Handbook (chapter 10), Podgorsak ed., International Atomic Energy Agency, Vienna.

http://www-naweb.iaea.org/nahu/dmrp/pdf_files/Chapter10.pdf

IAEA 1998, "Accidental overexposure of radiotherapy patients in San José, Costa Rica", International Atomic Energy Agency", Vienna

http://www-pub.iaea.org/MTCD/publications/PDF/P027_scr.pdf

IAEA 2002 - TECDOC 1274, "Calibration of photon and beta ray sources used in brachytherapy: Guidelines on standardized procedures at Secondary Standards Dosimetry Laboratories (SSDLs) and hospitals".

http://www-pub.iaea.org/MTCD/publications/PDF/te_1274_prn.pdf

IAEA 2004 - TRS 430, "Commissioning and Quality Assurance of Computerized Planning Systems for Radiation Treatment of Cancer - International Atomic Energy Agency", Vienna

http://www-pub.iaea.org/MTCD/publications/PDF/TRS430_web.pdf

IAEA 2006 - TRS 398, "Absorbed Dose Determination in External Beam Radiotherapy: An International Code of Practice for Dosimetry based on Standards of Absorbed Dose to Water", v12 (5/06/2006)

http://www-naweb.iaea.org/nahu/dmrp/codeofpractice.shtm

IAEA 2006 - TRS 454, "Quality Assurance for Radioactivity Measurement in Nuclear Medicine" (Technical Reports Series n 454, STI/DOC/010/454).

IAEA 2007- QUATRO, "Comprehensive audits of radiotherapy practices: a tool for quality improvement, Quality Assurance Team for Radiation Oncology", International 
Atomic Energy Agency, Vienna

http://www-pub.iaea.org/MTCD/publications/PDF/Pub1297_web.pdf

IAEA 2007 - TECDOC 1540, "Specification and acceptance testing of Radiotherapy Treatment Planning Systems", International Atomic Energy Agency, Vienna http://www-pub.iaea.org/MTCD/publications/PDF/te_1540_web.pdf

IAEA 2007 - TECDOC 1543, "On-site Visits to Radiotherapy Centres: Medical Physics Procedures", International Atomic Energy Agency, Vienna http://www-pub.iaea.org/MTCD/publications/PDF/te_1543_web.pdf

IAEA 2007 - TRS 457, "Dosimetry in Diagnostic Radiology: An International Code of Practice" (Technical Reports Series No. 457, STI/DOC/010/457)

IAEA 2008 - TECDOC 1583, "Commissioning of Radiotherapy Treatment Planning Systems: Testing for Typical External Beam Treatment Techniques", International Atomic Energy Agency, Vienna

http://www-pub.iaea.org/MTCD/publications/PDF/te_1583_web.pdf

IAEA 2008, "Setting up a Radiotherapy Programme: Clinical, Medical Physics, Radiation Protection and Safety Aspects" (STI/PUB/1296)

http://www-pub.iaea.org/MTCD/publications/PDF/pub1296_web.pdf

IAEA 2008 "Comprehensive Audit, Quality Management Audits in Nuclear Medicine Practices", International Atomic Energy Agency, Vienna.

http://www-pub.iaea.org/MTCD/publications/PDF/Pub1297_web.pdf

IAEA 2009 - HHS 1, "Quality Assurance for PET and PET/CT Systems"

(Human Health Series No. 1, STI/PUB/1393)

IAEA 2009 - HHS 2, "Quality Assurance Programme for Screen Film Mammography" (Human Health Series No. 2, STI/PUB/1381)

IAEA 2009 - HHS 6, "Quality Assurance for SPECT Systems"

(Human Health Series No. 6, STI/PUB/1394)

IAEA 2009 - TRS 469, "Calibration of Reference Dosimeters for External Beam Radiotherapy" (Technical Reports Series n469, STI/DOC/010/469).

IAEA 2010 - HHS 4, "Comprehensive Clinical Audits of Diagnostic Radiology Practices: A Tool for Quality Improvement", International Atomic Energy Agency, Vienna.

(Human health Series No. 4, STI/PUB/1425)

IAEA 2011 - GSR Part 3, "Radiation Protection and Safety of Radiation Sources: International Basic Safety Standards, General Safety Standards (Interim Edition)", International Atomic Energy Agency, Vienna

http://www-pub.iaea.org/MTCD/publications/PDF/p1531interim_web.pdf

IAEA 2011 - HHR 4, "Implementation of the International Code of Practice on Dosimetry in Diagnostic Radiology (TRS 457). Review of Results", (Human Health Reports $n^{\circ} 4$, STI/PUB 1498).

IAEA 2012, "Acceptance Testing, Commissioning and Quality Control of Record and Verify Systems for Radiation Treatment of Cancer" (Human Health Report - à paraître).

ICRP 2000 - Publication 85, "Avoidance of radiation injuries from medical interventional procedures. A report of the International Commission on Radiological Protection", Annals of the ICRP 30(2).

ICRP 2000 - Publication 86, "Prevention of accidental exposures to patients undergoing radiation therapy. A report of the International Commission on Radiological Protection", Annals of the ICRP 30(3) : voir CIPR 2003. 
ICRP 2007, "The 2007 Recommendations of the International Commission on Radiological Protection", Annals of the ICRP 37 (2-4) : voir CIPR 2007.

ICRP 2008 - Publication 106, "Radiation Dose to Patients from Radiopharmaceuticals - Addendum 3 to ICRP Publication 53", Annals of the ICRP 38 (1-2).

ICRP 2009 - Publication 112, "Preventing Accidental Exposures from New External Beam Radiation Therapy Technologies", Annals of the ICRP 39 (4).

ICRU (International Commission on Radiation Units) 1976, "Report 24: Determination of Absorbed Dose in a Patient Irradiated by Beams of X or Gamma Rays in Radiotherapy Procedures", ICRU, Behesda, MD.

ICRU 1996, "Report 54: Medical Imaging - The Assessment of Image Quality", ICRU, Behesda, MD.

ICRU 2002, "Report 67: Absorbed-Dose Specification in Nuclear Medicine", Journal of the ICRU 2(1).

ICRU 2003, "Report 70: Image quality in chest radiography", Journal of the ICRU 3(2).

ICRU 2005, "Report 74: Patient Dosimetry for X Rays used in Medical Imaging", Journal of the ICRU $\mathbf{5}(2)$.

ICRU 2008, "Report 79: Receiver Operating Characteristic Analysis in Medical Imaging", Journal of the ICRU 8(1).

ICRU 2009, "Report 82: Mammography - Assessment of Image Quality", Journal of the ICRU 9(2).

ICRU 2011, "Report 85: Fundamental Quantities and Units for lonizing Radiation", Journal of the ICRU 11(1).

IEC 2000, Radiotherapy Equipment. Co-ordinates, Movements and Scales, Report IEC 61217, International Electrotechnical Commission (IEC), Geneva.

IEC 2005, Medical Electrical Equipment. Safety of Radiotherapy Record and Verify Systems. Report IEC 62274, International Electrotechnical Commission (IEC), Geneva.

IOMP 2010, Policy statement $n^{\circ} 1$, "The medical physicist, role and responsibilities".

IRSN 2008, Mesure de la dose absorbée dans les faisceaux de photons de très petites dimensions utilisés en radiothérapie stéréotaxique. Rapport final du groupe de travail IRSN/SFPMISFRO, DRPH/SER n²008-18.

IRSN 2009, Reconstructions dosimétriques en neuroradiologie interventionnelle au Centre Hospitalier Universitaire Hautepierre de Strasbourg, Rapport d'expertise IRSN_reconstitutions_dosimetriques_neuroradiologie_interventionnelle_CHU-Hautepierre-Strasbourg.pdf

IRSN 2010, Exposition de la population française aux rayonnements ionisants liée aux actes de diagnostic médical en 2007, Rapport InVS-IRSN -2010.

Kervern G-Y 1995, Éléments fondamentaux des cindyniques, Economica.

Kramer R, Khoury HJ \& Vieira JW 2008, "CALDose_X, a software tool for the assessment of organ and tissue absorbed doses, effective dose and cancer risks in diagnostic radiology", Physics in Medicine and Biology, 53(22), 6437-645

http://iopscience.iop.org/0031-9155/53/22/011/pdf/0031-9155_53_22_011.pdf 
Lassmann M, Chiesa C, Flux G \& Bardiès M 2011, "EANM Dosimetry Committee guidance document: good practice of clinical dosimetry reporting" ,European Journal of Nuclear Medicine and Molecular Imaging, 38(1), 192-200

http://www.eanm.org/publications/guidelines/

EANM_guidance_document_good_dosimetry_reporting.pdf

LNHB 2006, Guide d'utilisation et de contrôle qualité des activimètres, Laboratoire National Henri Becquerel, NT LNHB 2006/03.

MEAH 2005-2009, Recueil des bonnes pratiques organisationnelles en radiothérapie, Mission nationale d'expertise et d'audit hospitalier, Éditions Berger Levrault, 3 tomes téléchargeables depuis http://www.anap.fr

MEAH 2007, Organisation des services d'imagerie, Mission nationale d'expertise et d'audit hospitalier, Édition Berger Levrault, téléchargeable depuis http://www.anap.fr

Meghzifene A \& Nüsslin F 2011, "Do medical physicists have a role in case of a nuclear or radiological emergency?", Physica Medica 27(3), 121.

Nelson R E, Stears J G, Barnes G T \& Gray J E 1992, "Acceptance testing of radiologic systems: experience in testing 129 imaging systems at two major medical facilities", Radiology, 183(2), 563-567.

Nüsslin F, Smith, P 2011, "Medical Physics now classified internationally as a profession", Medical Physics 38(8), i-i.

Ortholan C, Estivalet S, Barillot I, Costa A, Gérard JP 2007, "Guide des procédures de radiothérapie externe 2007", Cancer/Radiothérapie 11, 329-330.

Pawlicki T, Dunscombe P B, Mundt A J, Scalliet P. editors 2010, Quality and Safety in Radiotherapy, Taylor \& Francis.

Reason J 1993, L'erreur humaine, coll. « Le Travail Humain », Presses Universitaires de France (trad. JM Hoc, de Human Error, 1990, Cambridge University Press).

SFMN 2012, Livre blanc de la médecine nucléaire, Société Française de Médecine Nucléaire, http://www.sfmn.org/index.php/livre-blanc-de-la-medecine-nucleaire

SFPM 2001, Rapport 2001 sur la Physique Médicale en France, rédigé avec la participation du Syndicat National des Physiciens des Établissements Hospitaliers Privés et Publics dans le cadre du plan cancer 2001-2005.

SFPM 2003, Utilisation des références métrologiques nationales de dose absorbée dans l'eau et application du protocole de dosimétrie AIEA TRS n`398 aux faisceaux de photons de haute énergie, rapport d'un groupe de réflexion BNM-LNHB / LCIE / SFPM.

SFPM 2004 - Rapport n²1, Dosimétrie des explorations diagnostiques en radiologie.

SFPM 2007, Guide méthodologique pour l'élaboration des Plans d'Organisation de la Physique Médicale (POPM).

SFPM 2007 - Rapport n²3, Contrôle de qualité spécifique en IRM : développement et réalisation d'un objet-test multimodal.

SFPM 2008, Guide pour la pratique quotidienne de la dosimétrie in vivo en radiothérapie externe.

SFPM 2009 - Rapport n²5, Contrôle de qualité d'une installation de simulation virtuelle.

SFPM 2010 - Rapport n² 26, Contrôles de qualité en radiothérapie conformationnelle avec modulation d'intensité (RCMI). 
SFPM 2010 - Rapport n²7, Recommandations pour la mise en service et l'utilisation d'un système de planification de traitement en radiothérapie (TPS).

SFR-SFMN 2005, Guide du bon usage des examens d'imagerie médicale - Recommandations pour les professionnels de santé, Société Française de Radiologie et Société Française de Médecine Nucléaire, http://www.sfmn.org/?p=305 (disponible aussi sur le site de la HAS).

SFR 2010, Guide des procédures radiologiques : Critères de qualité et optimisation des doses, Société Française de Radiologie http://www.sfrnet.org/sfr/professionnels/5referentiels-bonnes-pratiques/guides/guide-procedures-radiologiques/index.phtml

SFRO 2007, Guide des procédures de radiothérapie externe, Société Française de Radiothérapie Oncologique, http://www.sfro.org/francais/Guide RT 2007.pdf

Stabin MG, Sparks RB \& Crowe E 2005, "OLINDA/EXM: the second-generation personal computer software for internal dose assessment in nuclear medicine" , Journal of Nuclear Medicine, 46(6), 1023-1027.

Stabin MG 2008, "Uncertainties in Internal Dose Calculations for Radiopharmaceuticals", Journal of Nuclear Medicine, 49(5), 853-860.

Tapiovaara M 2006, "Relationships Between Physical Measurements and User Evaluation of Image Quality in Medical Radiology: A review", Report STUK-A219 http:// www.stuk.fi/julkaisut/stuk-a/stuk-a219.html 


\section{KIVSDJHIQWQWRQDQ $\square$ OTWEOQN}

